\title{
DERMATOGLYPHIC PATTERNS AMONG LEBANESE MEDICAL STUDENTS OF BAU
}

\section{Ezzat A. El-Sawwa ${ }^{* 1}$, Mahmoud M. Mahfouz ${ }^{2}$.}

*1 Professor of Anatomy and Embryology, Faculty of Physical Therapy, Pharos University, Egypt.

2 Professor of Medicine, Faculty of Medicine, Beirut Arab University, Lebanon.

\section{ABSTRACT}

\begin{abstract}
Introduction: Dermatoglyphics has a potential contribution to biological anthropology and population genetics. The present study aims to detect the percentages of dermal ridge patterns' distribution among both sexes of medical students of Beirut Arab University with the intent to provide data that can serve as a control group in the future dermatoglyphic studies.
\end{abstract}

Materials and Methods: 50 males and 50 females of Lebanese medical students were taken randomly from all students of faculty of medicine of Beirut Arab University.

Results: The total distributions of fingertip patterns for both hands were $9.4 \%$ for arches, $44.4 \%$ for ulnar loops, $6.2 \%$ for radial loops and $40.0 \%$ for whorls for male students, $8.6 \%$ for arches, $46.4 \%$ for ulnar loops, $6.6 \%$ for radial loops $38.4 \%$ for whorls for females. Radial loops had the least distribution among both hands of males with nearly equal distribution between the ten fingers. Same results were found in both hands of females, with more inclination to the left index. For the palmar dermatoglyphic, the mean atd angle in males was $44.6 \pm$ 5.795847 for the right hand and $45 \pm 6.586938$ for the left hand with no significant difference. In females it was $44.94 \pm 4.528414$ for the right hand and $46.14 \pm 7.056651$ for the left hand with no significant difference. The results for the Pattern intensity index was 13.02 for both sexes, for the Dankmeijer's index was 22.959 for both sexes and for the Furuhata's index was 75.676 for both sexes. More than 3 fingers' were concordant in the present work in both sexes $80 \%$.

Conclusion: For finger tips, loops had the highest ratios, arches were the least, and whorls were in between with no significant differences between both hands and in both sexes. In the palm, the mean atd angle was around $45^{\circ}$ for both hands and in both sexes.

KEY WORDS: Arch, Radial loop, Ulnar loop, whorl, atd angle, Various dermatoglyphic indices.

Address for Correspondence: Prof. Dr. Ezzat El-Sawa, Professor of Anatomy and Embryology, Faculty of physio-therapy, Pharos University, Egypt. E-Mail: ezzatanat_1@yahoo.com

\begin{tabular}{|l|l|}
\multicolumn{3}{|c|}{ Access this Article online } \\
\hline Quick Response code & Web site: International Journal of Anatomy and Research \\
ISSN 2321-4287 \\
www.ijmhr.org/ijar.htm
\end{tabular}

\section{INTRODUCTION}

Dermatoglyphics is the study of patterns of fingers, toes, palms and soles. Fingerprints will not change so long as there is no serious injury. Both hands differ and also identical twins show differences. All primates have ridges [1].

Each individual exhibits unique finger and palm print configurations determined by the genetic profile of their parents [2].

There are 3 basic patterns in the prints; arches, loops and whorls. Arches are either simple or tented. Loops include radial and ulnar loops. Whorls have many subtypes including simple whorl (concentric or spiral), double loops, central pocket whorl and accidental whorl which represents two or more patterns such as a loop 
and a whorl or triple loops (fig. 1). 60-65\% of the population has loops, $5 \%$ has arches and 30-35\% has whorls [1,3-5].

Fig. 1: Schematic drawings of fingertip patterns with boldly traced type lines. A, simple arch; B, tented arch; C and $D$, loop (ulnar or radial);E, simple whorl; $F$, central pocket whorl; G, double loop whorl; $\mathrm{H}$, accidental whorl [5].

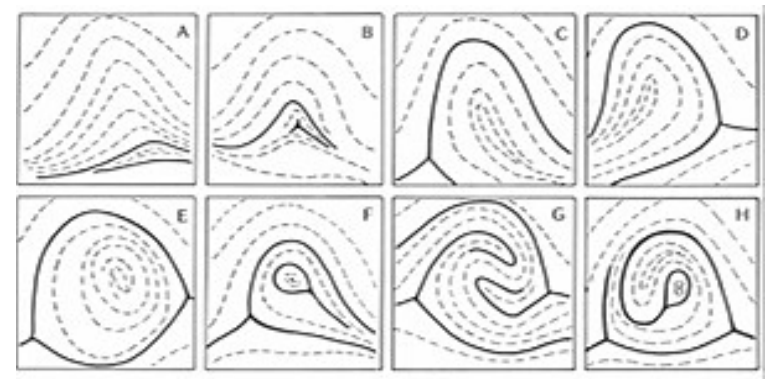

A study on 400 healthy Nigerian students reveals that: Ulnar loops polarized preferentially to digits III, IV and V and radial loops to digit II. Female subjects had higher counts of radial loops $(p<0.001)$ than the males. Male subjects had a higher whorl count than the females $(p<0.05)$ [6].

Frequency distribution of finger pattern types among major Mongoloid tribal populations in India showed that whorls were the most prevalent patterns among both males (52.19\%) and females (55.69\%), followed by loops $(47.70 \%$ in males and $2.81 \%$ in females) for both left and right sides combined [7].

The general distribution of finger print patterns among the students of medical school of Ajmer, Indea, showed high frequency (51.87\%) of loops whereas whorls were moderate $(35.83 \%)$ and arches were least (12.30\%) in frequency [8].

Studying of 200 medical students (100 male \& 100 female) belonging to the age group 18- 25 of Kasturba Medical College, Mangalore, India, showed that each finger print is unique; loops are the most commonly occurring fingerprint pattern while arches are the least common. Males have a higher incidence of whorls and females have a higher incidence of loops [9].

The dermal ridges on the fingertips, i.e., fingerprints, are arranged in patterns and classified based on the number of tri-radii present [10].

Pattern intensity refers to the complexity of ridge configurations. It can be expressed by counting the number of triradii present. According to the number of triradii, a digit can have a pattern intensity $0-3$. The simple arch, which lacks a triradius, is assigned the number 0 , the tented arch and loop are both assigned 1, as each has one triradius, and typically, the whorl and it's subtypes are assigned 2, as they have two triradii $[10,11]$. The most widely used palmar character is the measurement of atd angle [3]. Concordance is the presence of similar patterns on homologous fingers of right and left hands, and it is an example of fluctuating asymmetry caused by environmental disturbance [12].Greater concordance in fingerprint patterns is present among control group than among cases [13].

Previous studies have reported the proportional variation in fingerprint pattern types among Thai populations [14] and other ethnicities [15 - 18]. For example, the arch pattern type is present at a high frequency in African (17.5\%) [15] compared to Indian (5.6\%) [16], Thai (3.2\%) [17], and New Zealand (0.8\%) [18] Populations.

The present study aims to detect the percentages of dermal ridge patterns' distribution among the medical students of Beirut Arab University of both sexes with the intent to provide data that can serve as a control group in the future dermatoglyphic studies.

\section{MATERIALS AND METHODS}

100 Lebanese medical students, 50 males and 50 females were taken randomly from all students of faculty of medicine of Beirut Arab University. Personnel data and consent were recoded for each student [appendix-1]. Non Lebanese parental nationality, congenital malformations, like congenital heart diseases and musculo-skeletal abnormalities were excluded.

Both palms were scanned using Adobe Photoshop CS6 at a resolution of 600 dots per in (DPI). Finger patterns were also read by magnifying lens and recorded in each sheet. Palmar triradii were studied. The Triradius present below medial four fingers are named $a, b, c$ and $d$ starts from index finger to little finger, the Triradius present between thenar and hypothenar eminence were named as $(t)$. When two (a) or two (d) triradii were encountered, the more radial and more ulnar triradius, respectively, was used to determine the atd angle. When more than one $t$ triradius was encountered in a single 
print, only the more proximal triradius was used ( $t$ instead of $t^{\prime}$ and $t^{\prime}$ instead of $t^{\prime \prime}$ ) in accordance with the method proposed by David (1981a) (fig. 2) [19]. The atd angle was drown by photoshop.

Fig. 2: The corrected atd angle [19].

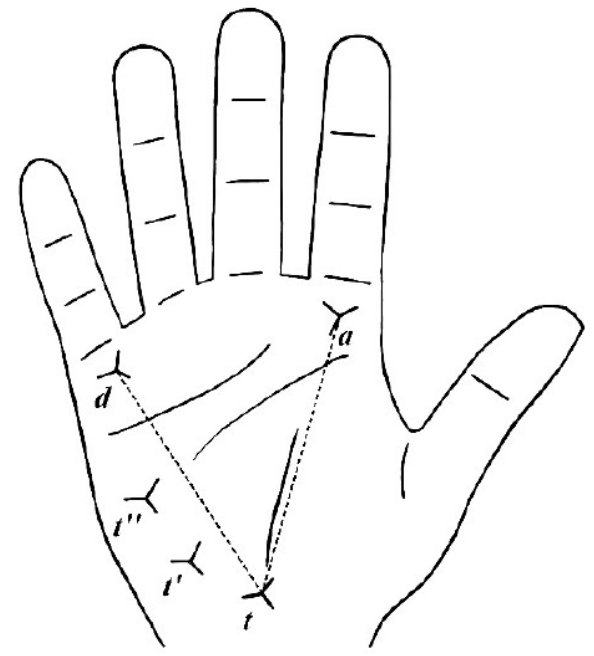

The Various dermatoglyphic pattern indices calculated from the obtained results are as follows: Pattern intensity index $=[(2 \times \%$ whorl $+\%$ loop $)$ $\div 10][20,21,22,23]$.

Dankmeijer's index $=[(\%$ arches $\div \%$ whorl $) x$ 100][20, 21, 24].

Furuhata's index $=[(\%$ whorl $\div \%$ loop $) \times 100]$ $[20,21,25]$.

Data were statistically analyzed using chi squared test with Yate's correction and Unpaired Student " $\mathrm{t}$ " test. Differences were considered significant if $p$ values were less than 0.05 [26, 27].

\section{RESULTS}

Table 1: Distribution of fingertip patterns for both hands of male students.

\begin{tabular}{|c|c|c|c|c|c|c|}
\hline & \multicolumn{2}{|c|}{ Right } & \multicolumn{2}{c|}{ Left } & \multicolumn{2}{c|}{ Total } \\
\hline & $\mathrm{N}$ & $\%$ & $\mathrm{~N}$ & $\%$ & $\mathrm{~N}$ & $\%$ \\
\hline Arches & 21 & 8.4 & 26 & 10.4 & 47 & 9.4 \\
\hline Ulnar loop & 111 & 43.6 & 111 & 44.4 & 222 & 44.4 \\
\hline Radial loop & 17 & 6.8 & 14 & 5.6 & 31 & 6.2 \\
\hline Whorls & 101 & 41.2 & 99 & 39.6 & 200 & 40 \\
\hline Total & 250 & 100 & 250 & 100 & 500 & 100 \\
\hline
\end{tabular}

The differences were insignificant for the chisquare (X2) with Yates' $p$-value $=0.9234802$ at 3 degree of freedom.

A total of 100 medical students participated in the present study, out of which 50 were males and 50 were females. The following results were encountered:

For the percentage of distribution of fingertip' patterns among the ten fingers, nearly equal percentages were found for both right and left hands of male students (table 1 ), and female students (table 2). The differences were not significant.

Table 2: Distribution of fingertip patterns for both hands of female students.

\begin{tabular}{|c|c|c|c|c|c|c|}
\hline & \multicolumn{2}{|c|}{ Right } & \multicolumn{2}{c|}{ Left } & \multicolumn{2}{c|}{ Total } \\
\hline & N & $\%$ & N & $\%$ & N & $\%$ \\
\hline Arches & 19 & 7.6 & 24 & 9.6 & 43 & 8.6 \\
\hline Ulnar loop & 114 & 45.6 & 118 & 47.2 & 232 & 46.4 \\
\hline Radial loop & 25 & 10 & 8 & 3.2 & 33 & 6.6 \\
\hline Whorls & 92 & 36.8 & 100 & 40 & 192 & 38.4 \\
\hline Total & 250 & 100 & 250 & 100 & 500 & 100 \\
\hline
\end{tabular}

The differences were insignificant for the chi-square $(X 2)$ with Yates' $p$-value $=0.03801539$ at 3 degree of freedom.

Also nearly equal ratios for fingertip patterns distribution in both sexes were present (tab. 3). The differences were not significant.

Table 3: Distribution of fingertip patterns in both sexes.

\begin{tabular}{|c|c|c|c|c|c|c|}
\hline & \multicolumn{2}{|c|}{ Males } & \multicolumn{2}{c|}{ Females } & \multicolumn{2}{c|}{ Total } \\
\hline & N & $\%$ & N & $\%$ & N & $\%$ \\
\hline Arches & 47 & 9.4 & 43 & 8.6 & 90 & 9 \\
\hline Ulnar loop & 222 & 44.4 & 232 & 46.4 & 454 & 45.4 \\
\hline Radial loop & 31 & 6.2 & 33 & 6.6 & 64 & 6.4 \\
\hline Whorls & 200 & 40 & 192 & 38.4 & 392 & 39.2 \\
\hline Total & 500 & 100 & 500 & 100 & 1000 & 100 \\
\hline
\end{tabular}

The differences were insignificant for the chi-square (X2) with Yates' $p$-value $=0.93629017$ at 3 degree of freedom.

From the previous tables the radial loops had lower percentages when compared with ulnar loops. 8 Radial loops were found on the left hands in females; mainly on the index finger (5), two on the left middle and one on the left little finger. Whereas 25 radial loops were recorded on the right hands of female students with about equal distributions between the five fingers. In males, about equal numbers were recorded for both right (17) and left (14) with nearly equal distributions between the five fingers.

The results of the present study for both sexes revealed that arches had the lower percentage $9 \%$, followed by the whorls $39.2 \%$, whereas loops had the higher ratios $51.8 \%$. 
For the palmar dermatoglyphic, the mean for the atd angle of the right hands in males was $44.6 \pm$ 5.795847 and that for the left hand was $45 \pm$ 6.586938 , the difference was not significant at 98 degrees of freedom table 4.

Table 4: Differences between atd angles of both right and left hands of male students.

\begin{tabular}{|c|c|c|}
\hline & \multicolumn{2}{|c|}{ Males } \\
\hline & $\begin{array}{c}\text { Rt hand } \\
(\mathbf{N}=\mathbf{5 0})\end{array}$ & $\begin{array}{c}\text { Lt hand } \\
(\mathbf{N}=\mathbf{5 0})\end{array}$ \\
\hline Mean & 44.6 & 45.6 \\
\hline Standard deviation & 5.795847 & 6.586938 \\
\hline t-test & \multicolumn{2}{|c|}{0.00000023} \\
\hline p-value & \multicolumn{2}{|c|}{ Not significsant } \\
\hline
\end{tabular}

Fig. 3:Photoshop of the palm of the left hand showing (a $\&$ d) triradii at the roots of the index and little fingers. Note that two proximal ( $\mathrm{t} \& \mathrm{t}^{\prime}$ ) triradii were present in this condition and that the most proximal $(t)$ triradius was included in the measurement of atd angle.

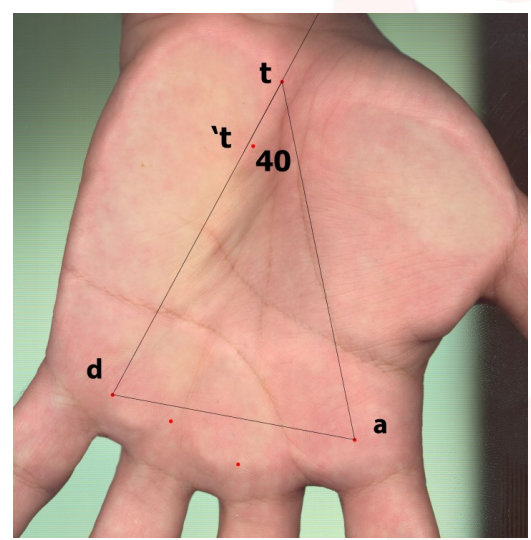

For the palmar dermatoglyphic, the mean for the atd angle of the right hands in females was 44.94 \pm 4.528414 and that for the left hand was 46.14 \pm 7.056651 , the difference was not significant at 98 degrees of freedom table 5.

Table 5: Difference between atd angles of both hands of female students.

\begin{tabular}{|c|c|c|}
\hline & \multicolumn{2}{|c|}{ Females } \\
\hline & $\begin{array}{l}\text { Rt hand } \\
\text { (N=50) }\end{array}$ & $\begin{array}{c}\text { Lt hand } \\
\text { (N = 50) }\end{array}$ \\
\hline Mean & 44.94 & 46.14 \\
\hline Standard deviation & 4.528414 & 7.056651 \\
\hline t-test & \multicolumn{2}{|c|}{0.20239972} \\
\hline p-value & \multicolumn{2}{|c|}{ Not significsant } \\
\hline
\end{tabular}

The various dermatoglyphic indices table 6:

o The pattern intensity index was 13.06 for males and 12.98 for females.

o Dankmeijer's index was 23.5 for males and 22.396 for females.

o Furuhata's index was 79.051 for males and 72.453 for females.
Table 6: The various dermatoglyphic indices for both males and females

\begin{tabular}{|c|c|c|c|c|}
\hline Study data & Gender & $\begin{array}{c}\text { Pattern } \\
\text { intensity index }\end{array}$ & $\begin{array}{c}\text { Dankmeijer's } \\
\text { index }\end{array}$ & $\begin{array}{c}\text { Furuhata's } \\
\text { index }\end{array}$ \\
\hline \multirow{2}{*}{$\begin{array}{c}\text { Medical students } \\
\text { of BAU }\end{array}$} & Males & 13.06 & 23.5 & 79.051 \\
\cline { 2 - 5 } & Females & 12.98 & 22.396 & 72.453 \\
\cline { 2 - 5 } & Males + Females & 13.02 & 22.959 & 75.676 \\
\hline
\end{tabular}

Table 7: Distribution frequency of fingertip patterns among the five fingers of both right and left hands in male students.

\begin{tabular}{|c|c|c|c|c|c|c|c|c|c|c|c|c|c|c|c|}
\hline & & & & & \\
\hline & Right & Left & Both & Right & Left & Both & Right & Left & Both & Right & Left & Both & Right & Left & Both \\
\hline & 50 & 50 & 100 & 50 & 50 & 100 & 50 & 50 & 100 & 50 & 50 & 100 & 50 & 50 & 100 \\
\hline$A$ & 4 & 4 & 4 & 16 & 22 & 19 & 14 & 18 & 16 & 6 & 6 & 6 & 2 & 2 & 2 \\
\hline L & 38 & 38 & 38 & 36 & 26 & 31 & 50 & 46 & 48 & 38 & 38 & 38 & 60 & 74 & 67 \\
\hline RL & 4 & 4 & 4 & 8 & 8 & 8 & 12 & 6 & 9 & 2 & 4 & 3 & 8 & 6 & 7 \\
\hline & 54 & 54 & 54 & 40 & 44 & 42 & 24 & 30 & 27 & 24 & 52 & 53 & 30 & 18 & \\
\hline
\end{tabular}

$1=$ thumb, II = index, III = middle, IV = ring, $\mathrm{V}=$ little finger.

$\mathrm{A}=$ Arch, $\mathrm{UL}=$ Ulnar loop, $\mathrm{RL}=$ Radial loop, $\mathrm{W}=$ Whorl.

Table 8: Distribution frequency of fingertip patterns among the five fingers of both right and left hands in female students.

\begin{tabular}{|c|c|c|c|c|c|c|c|c|c|c|c|c|c|c|c|}
\hline & & & & & \\
\hline & Right & Left & Both & Right & Left & Both & Right & Left & Both & Right & Left & Both & Right & Left & \\
\hline & 50 & 50 & 100 & 50 & 50 & 100 & 50 & 50 & 100 & 50 & 50 & 100 & 50 & 50 & 10 \\
\hline A & 2 & 2 & 2 & & 14 & 13 & 16 & 18 & 17 & & 6 & 5 & & 6 & \\
\hline JL & 42 & 46 & 44 & 36 & 28 & 32 & 48 & 52 & 50 & 32 & 40 & 36 & 64 & 70 & \\
\hline RL & 10 & 0 & 5 & 10 & 8 & 9 & 12 & 4 & 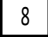 & 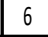 & 0 & 3 & 12 & 2 & \\
\hline & 46 & 52 & 49 & 42 & 50 & 46 & 24 & 26 & 25 & 58 & 54 & 56 & 20 & 2 & \\
\hline
\end{tabular}

$1=$ thumb, $I I=$ index, $I I I=$ middle, IV = ring, $V=$ little finger. $\mathrm{A}=$ Arch, UL = Ulnar loop, $\mathrm{RL}=$ Radial loop, $\mathrm{W}=$ Whorl.

The highest concordant percentages were recorded for 4 fingers, followed by 5 and 3 fingers. The lowest concordant rates were recorded for 2 fingers, whereas none or one finger concordance were almost none for both sexes table 9.

Table 9: Finger patterns' concordance for both sexes in the present study.

\begin{tabular}{|c|c|c|c|c|c|c|}
\hline \multirow{2}{*}{$\begin{array}{c}\text { Concordant } \\
\text { fingers }\end{array}$} & \multicolumn{2}{|c|}{ Males } & \multicolumn{2}{c|}{ Females } & \multicolumn{2}{c|}{ Total } \\
\cline { 2 - 7 } & $\mathbf{N}$ & $\%$ & N & $\%$ & N & $\%$ \\
\hline 5 Fingers & 10 & 20 & 10 & 20 & 20 & 20 \\
\hline 4 Fingers & 20 & 40 & 23 & 46 & 43 & 43 \\
\hline 3 Fingers & 13 & 26 & 7 & 14 & 20 & 20 \\
\hline 2 Fingers & 7 & 14 & 9 & 18 & 16 & 16 \\
\hline None & 0 & 0 & 1 & 2 & 1 & 1 \\
\hline Total & 50 & 100 & 50 & 100 & 100 & 100 \\
\hline
\end{tabular}

The chi-square distribution was non-significant at 4 degrees of freedom (Yates' $p$-value: $0.83440588)$.

\section{DISCUSSION}

The dermatglyphic patterns of the present study 
were done sex wise and side wise. The four fingerprint patterns highlighted in the present study were arches, ulnar loops, radial loops and whorls. Pattern indices were recorded and the means of palmar atd angle were tabulated. Higher frequencies of ulnar loops were recorded in the present study for the right hand 43.6 and 44.4 for the left hand in male students with 44.4 $\%$ for both hands as the difference was insignificant (table 1). Also the same results were recorded for female students which were 45.6, 47.2 and $46.4 \%$ for the right hand, left hand and both hands respectively, as the difference was insignificant (table 2). When the percentages of both sexes were compared, the difference also was insignificant, so the ratios for both sexes summed were 9.0, 45.4, 6.4 and $39.2 \%$ for arches, ulnar loops, radial loops and whorls respectively (table 3 ). These insignificant type, sex and side wise distribution in the present study was consistent with the study done on medical students 2006[28].

The previous results were in accordance with five Indian studies $[8,9,28,29,30]$, two Nigrean studies [15, 31], two Sri Lanka studies [21, 32], Bengal [33], Tunisia [34], Black Americans (USA) [35], Vietnamese [36], and Caucasian [37] where loops were more prevalent than whorls. On the other hand, the present results were in contrast to the studies conducted by some authors in Australia [38], New Zealand [18], and India $[7,39]$ where the whorls predominate over the ulnar loops in both hands of males and females.

Higher percentages of arch pattern were found on the index and middle fingers of both hands for male and female students in the present work (table 6-7), more in the left index in males and in the left middle finger in females. These results were in accordance with two studies on Indian people in 2015 [28, 40], on Sri Lanka people 2013 [21] and on Thailand people 2013 [14].

Radial loop was the least frequent pattern recorded in the present study $6.4 \%$ (table 3 ). It was seen on all the ten digits with a slight higher inclination to the index and middle fingers of right and left hands in both sexes. These results were in accordance with the records for the index finger $[28,21,14,6]$ whereas the radial loops were either absent or with low records on the remaining digits.

Ulnar loop was the highest frequent pattern in the present study. It showed highest record for the little finger of both the right and left hands in both sexes, followed by the middle and then the thumb in female students, with equal records on both the thumb and ring fingers in males. These results of ulnar loop for the little, middle and thumb fingers in the present study were consistent with the studies on Muslim population from India in 2015 [29], Nigerian students' 2011 [6], Indian people 2009 [7], and among Sinhalese people in Sri Lanka 2013 [21].

Whorls were the $2^{\text {nd }}$ frequent pattern in the present study. Higher frequencies were recorded on the thumb, ring and index fingers. A result which was in accordance with an Indian study 2009 [7], a Sri Lanka study 2013 [21] with higher records on the ring finger, an Indian people 2015 $[28,40]$ with also higher records on the ring finger. A $3^{\text {rd }}$ Indian study in 2015 [41] recoded high frequencies for the whorls on the index and thumb, with nearly equal ratios on the middle and ring fingers. Also the present results for whorls were consistent with a Thailand study 2013 [14], an Indian study 2006 [28] for the ring, thumb and index fingers.

The three indices of the present study for both males and females were slightly higher than those recorded in the Indian study in 2015 [29], but the Pattern intensity index for both males and females in the present study were nearly equal to the study in 2013 [21] whereas the other two indices were also higher.

The results for fingertip patterns' concordance in the present study showed that three and more finger concordance represents more than $80 \%$. A result that agreed with a previous one among Thai Adolescents [14].

\section{ABBREVIATIONS}

$A$ - arch.

RL - radial loop.

UL - ulnar loop.

W - whorl.

\section{CONCLUSION}

The distribution of fingertip patterns where loops predominate over whorls and arches, concordance rate over three fingers and mean atd 
angles of 45 in both hands and for both sexes makes the present sample of BAU students as a control group for future studies.

\section{Conflicts of Interests: None}

\section{REFERENCES}

[1]. Cummins $\mathrm{H}$ and Midlo WC. Fingerprints, Palms and Soles: An Introduction to Dermatoglyphics. 2nd ed. New York: Dover Publication. 1961:1-319.

[2]. Holt SB. The Genetics of Dermal Ridges. 1st ed. Charles C Thomas: Springfield, Illinois. 1968.

[3]. Loesch DZ. Quantitative dermatoglyphics: classification, genetics, and pathology. 1st ed. Oxford: Oxford University press. 1983:1-450.

[4]. Galton F. Finger Prints. 1st ed. London and New York: Macmillan and Co. 1892:1-211.

[5]. Alter M. Dermatoglyphic analysis as a diagnostic tool. Medicine 1966; 46(1):35-56.

[6]. Anibor E, Igbigbi PS, Avwioro OG, Okpor A. Palmar and digital dermatoglyphic patterns in the Ndokwas of Delta State, Nigeria. Afr J Med Sci 2011 Sep; 40(3): 181-5.

[7]. Banik SD, Pal P and Mukherjee DP. Finger dermatoglyphic variations in Rengma Nagas of Nagaland India. Coll Antropol 2009 Mar; 33(1): 315.

[8]. Bharadwaja A, Saraswat PK, Aggarwal SK, Banerji P and Bharadwaja S. pattern of finger-prints in different abo blood groups.JIAFM2004;26(1):6-9.

[9]. Rastogi P and Pillai KR. A study of fingerprints in relation to gender and blood group. J Indian Acad Forensic Med 2010; 32(1):11-14.

[10]. Holt SB. Quantitative genetics of fingerprint patterns. Brit Med Bull 1961; 17: 247-250.

[11]. Schawmann B and Alter M. Dermatoglyphics in Medical Disorders. New York: Springer-Verlag. 1st ed. 1976; 18-22.

[12]. Palmar AR and Strobeck C. Fluctuating asymmetry: Measurement, analysis, and patterns. Ann Rev Ecol Syst 1986; 17: 391-421.

[13]. Naugler CT and Ludman MD. A case-control study of fluctuating dermatoglyphic asymmetry as a risk marker for developmental delay. Am J Med Genet 1996; 66: 11-4.

[14]. NaNnakorn S, Kutanan W and Chusilp K. An Exploration of Fingerprint Patterns and Their Concordance among Thai Adolescents. Chiang Mai J Sci 2013; 40(3): 332-343.

[15]. Eboh DEO. Digital dermatoglyphic patterns of Anioma and Urhobo students in two tertiary institutions of Delta State Southern Nigeria. J Med Biomed Res 2012; 11(2): 90-6.

[16]. Nithin MD, Balaraj BM, Manjunatha B and CMestri $S$. Study of fingerprint classification and their gender distribution among South Indian population. $J$ Forensic Leg Med 2009;16(8):460-3.

[17]. Nanakorn S., Poosankam P. and Nanakorn A. An application of automated inkless fingerprint imaging software for fingerprint research. Second International Conference on Innovative Computing, Infor mation and Control, ICICIC 2007, art.no. 4427698.

[18]. Ching Cho. A finger dermatoglyphics of the New Zealand Samoans. Korean J Biol Sci 1998;2:507-11.

[19]. David TJ. The corrected atd angle. Human Heredity 1981(a); 31:283-285.

[20]. Kapoor N and Badiye A. Digital dermatoglyphics: A study on muslim population from India. Egyptian Journal of Forensic Medicine 2015;5:90-95.

[21].Wijerathne BTB, Rathnayake GK, Adikari SC, Amarasinghe $\mathrm{S}$, Abhayarathna PL and Jayasena AS. Sexual dimorphism in digital dermatoglyphic traits among Sinhalese people in Sri Lanka. J Physiol Anthropol 2013; 32(27):1-9.

[22]. Cummins H, Steggerda M. Finger prints in a Dutch family series. Am J Phys Anthropol 1935; 20: 19-4.

[23]. Basu A, Namboodiri KK. The relationship between total ridge count and pattern intensity index of digital dermatoglyphics. Am J Phys Anthropol 1971; 34: 165-73.

[24]. Dankmeijer J.Some anthropological data on finger prints. Am J Phys Anthropol 1938;23:377-88.

[25]. Furuhata T. The difference of the index of finger prints according to race. Japan Med World 1927; 7: 162-4.

[26]. Ludbrook, J. Analysis of $2 \times 2$ tables of frequencies: matching test to experimental design. International Journal of Epidemiology (2008); 37: 1430 -1435.

[27]. Altman DG. Confidence intervals for the number needed to treat. British Medical Journal 1998; 317: 1309-12.

[28]. Kanchan T, Chattopadhyay S. Distribution of fingerprint patterns among medical students. JIAFM 2006; 28(2): 65-8.

[29]. Bansal HD, Badiye AD and Kapoor NS. Distribution of Fingerprint Patterns in an Indian Population. Malaysian Journal of Forensic Sciences (2014); 5(2):18-21.

[30]. Srivastava RP. A study of finger prints of the Danguria Tharu of Uttar Pradesh (India). Am J Phys Anthropol 1963; 21: 69-76.

[31]. Boroffice RA. Digital dermatoglyphic patterns in a sample of the Nigerian population. Am J Phys Anthropol 1978; 49: 167-9.

[32]. Wijerathne BTB and Rathnayake GK. Association between digital dermatoglyphics and handedness among Sinhalese in Sri Lanka. Journal List F1000Res v.2; 2013 Nov 4; 2: 111. PMC3917648.

[33]. Chattopadhyay PK, Sharma PD. Finger dermatoglyphics of the Rarhi Brahmins of Bengal. Am J Phys Anthropol 1969; 30: 397-401.

[34]. Namouchi I. Anthropological significance of dermatoglyphic trait variation: an intra-Tunisian population analysis. Int J Mod Anthropol 2011; 4: 1227.

[35]. Qazi QH, Mapa HC, Woods J. Dermatoglyphics of American blacks. Am J Phys Anthropol. 1977; 47: 483-7.

[36]. Li H, Pan SL, Donnelly M, Tran D, Qin ZD, Zhang YF, Cheng X, Yin RX, Lin WX, Hoang V, Pham V, Qian J and Jin L. Dermatoglyph groups Kinh Vietnamese to MonKhmer. Int J Anthropol 2006; 21: 295-306. 
[37]. Schaumann BA and Alter M. Dermatoglyphics in Medical Disorders. New York: Springer-Verlag. 1st ed. 1976:1-265.

[38]. Cho C. Finger dermatoglyphics of Australian Aborigines in the Northern Territory of Australia. Korean J Biol Sci 2000; 4: 91-4.

[39]. Biswas S. Finger and palmar dermatoglyphic study among the Dhimals of North Bengal India. Anthropologist 2011; 13(3): 235-8.

[40]. Navit S, Chadha D, Khan SA, Singh RK, Johri N, Navit $P$, Sharma A and Bahuguna R. The Mystery of Handprints: Assesment and Correlation of Dermatoglyphics with Early Childhood Caries. A Case-Control Study. Journal of Clinical and Diagnostic Research. 2015 Oct, Vol-9(10): ZC44-ZC48
[41]. Bhardwaj N, Bhardwaj P, Tewari V and Siddiqui MS. Dermatoglyphic analysis of fingertip and palmer print patterns of obese children. $2015 ; 4(7)$ : 946949.

How to cite this article:

Ezzat A. El-Sawwa, Mahmoud M. Mahfouz. DERMATOGLYPHIC

PATTERNS AMONG LEBANESE MEDICAL STUDENTS OF BAU. Int J

Anat Res 2017;5(4.2):4546-4552. DOI: 10.16965/ijar.2017.332 